\title{
Update: Interim Guidance for Preconception Counseling and Prevention of Sexual Transmission of Zika Virus for Men with Possible Zika Virus Exposure - United States, August 2018
}

\author{
Kara D. Polen, MPH${ }^{1}$; Suzanne M. Gilboa, $\mathrm{PhD}^{1}$; Susan Hills, MBBS${ }^{2}$; Titilope Oduyebo, MD³ ; Katrin S. Kohl, MD, PhD ${ }^{4}$; \\ John T. Brooks, MD ${ }^{5}$; Alys Adamski, PhD ${ }^{1}$; Regina M. Simeone, MPH ${ }^{1}$; Allison T. Walker, $\mathrm{PhD}^{4}$; Dmitry M. Kissin, MD ${ }^{3}$; Lyle R. Petersen, MD²; \\ Margaret A. Honein, $\mathrm{PhD}^{1}$; Dana Meaney-Delman, $\mathrm{MD}^{1}$
}

\begin{abstract}
On August 7, this report was posted as an MMWR Early Release on the MMWR website (https://www.cdc.gov/mmwr).
\end{abstract}

Zika virus infection can occur as a result of mosquitoborne or sexual transmission of the virus. Infection during pregnancy is a cause of fetal brain abnormalities and other serious birth defects $(1,2)$. CDC has updated the interim guidance for men with possible Zika virus exposure who 1) are planning to conceive with their partner, or 2) want to prevent sexual transmission of Zika virus at any time (3). CDC now recommends that men with possible Zika virus exposure who are planning to conceive with their partner wait for at least 3 months after symptom onset (if symptomatic) or their last possible Zika virus exposure (if asymptomatic) before engaging in unprotected sex. CDC now also recommends that for couples who are not trying to conceive, men can consider using condoms or abstaining from sex for at least 3 months after symptom onset (if symptomatic) or their last possible Zika virus exposure (if asymptomatic) to minimize their risk for sexual transmission of Zika virus. All other guidance for Zika virus remains unchanged. The definition of possible Zika virus exposure remains unchanged and includes travel to or residence in an area with risk for Zika virus transmission (https:// wwwnc.cdc.gov/travel/page/world-map-areas-with-zika) or sex without a condom with a partner who traveled to or lives in an area with risk for Zika virus transmission. CDC will continue to update recommendations as new information becomes available.

\section{Review of Evidence}

Primarily transmitted through the bite of an infected Aedes aegypti mosquito, Zika virus can also be transmitted through unprotected sex (i.e., without correct and consistent use of a condom) with an infected partner. As of July 3, 2018, 52 cases of confirmed sexual transmission of Zika virus infection have been reported in the United States since 2015 (https://www.cdc. gov/zika/reporting/case-counts.html). Most documented reports of sexual transmission have involved transmission from a man to a woman (4); however, transmission also has been reported from a man to another man (5) and from a woman to a man (6).

Despite their limited generalizability to humans, preliminary data from animal studies suggest that sexual transmission of Zika virus during pregnancy might pose a higher risk to the fetus than mosquitoborne transmission. In female rhesus macaques, vaginal inoculation (as a model for sexual transmission) of Zika virus appeared to enhance viral dissemination to the female reproductive tract, compared with subcutaneous inoculation (7). In an immunodeficient mouse model, poorer maternal outcomes and higher fetal viral titers were observed when exposure was through sexual transmission rather than subcutaneous or intravaginal infection (8). Prevention of sexual transmission of Zika virus during pregnancy can reduce the risk for maternal infection and the potential for congenital Zika syndrome.

The risk for congenital Zika syndrome associated with maternal Zika virus infection during the periconceptional period is not known. Maternal infection with other viruses (e.g., rubella) during the periconceptional period have been associated with infection in the fetus and adverse pregnancy outcomes; although in some cases, the timing of infection relative to conception was uncertain (9-13). To date, there are no published data definitively linking Zika virus infection around the time of conception to adverse pregnancy outcomes.

Since the last update of this guidance on October 7, 2016 (3), additional evidence relevant to the assessment of risk for sexual transmission of Zika virus infection has been reported. A literature search of PubMed was performed to identify new human studies and data published in English since October 2016. References for included articles were also screened. Specific search terms used included "sexual transmission" or "semen" or "seminal fluid" and "Zika." The search yielded 15 publications, including case reports, case series, and nine cohort studies, which were reviewed for new, primary data.

Among the currently available reports of sexual transmission of Zika virus, the longest period from symptom onset in the index case to potential sexual transmission to a partner was between 32-41 days (14); most reports indicate much shorter intervals (4). The longest period after symptom onset at which replication-competent (i.e., potentially infectious) virus has been detected in semen by culture or cytopathic effect was 69 days (15). No other studies reported potentially infectious Zika virus in semen specimens obtained $\geq 40$ days after symptom onset (16-33).

Numerous publications have reported on the detection of Zika virus RNA in semen (4,15-41), although this might not indicate the presence of infectious virus at the time of sampling 
or correlate with the potential for sexual transmission of infectious virus. In the largest published cohort study to date, involving 184 men with confirmed symptomatic Zika virus infection from whom a baseline specimen and serial semen specimens were collected at 2-week intervals, Zika virus RNA shedding in semen declined during the 3 months after symptom onset (28). Overall, Zika virus RNA was detected in semen in 61\% (22 of 36 ); $43 \%$ ( 48 of 112); and 21\% (28 of 131) of participants from whom specimens were collected within 30, 31-60, and 61-90 days of illness onset, respectively. At $>90$ days after illness onset, semen of $\leq 7 \%$ of participants had detectable Zika virus RNA. The estimated mean time to clearance of Zika virus RNA from semen was 54 days (28). Another large cohort study conducted in Puerto Rico followed 117 men, 89 of whom provided semen specimens and reported similar results: at $>90$ days after illness onset 11\% (8 of 74) of men had detectable RNA in semen (Gabriela Paz-Bailey, Division of Vectorborne Diseases, National Center for Emerging and Zoonotic Infectious Diseases, CDC; personal communication, 2018) (32). Similar findings have been observed in smaller cohort studies $(16,17,23,25,29,37,39)$. Zika virus RNA has been detected in semen for as long as 370 days after symptom onset (17); however, detection for long periods is rare. Limited data suggest the incidence of Zika virus RNA shedding in semen and its persistence after infection are likely similar for symptomatic and asymptomatic men infected with Zika virus (40-42).

\section{Guidance for Preconception Counseling and Prevention of Sexual Transmission}

CDC's last interim guidance released in October 2016 was based on the maximum duration of detection of Zika virus RNA in semen. In the last interim guidance, CDC recommended that men with possible Zika virus exposure wait at least 6 months after symptom onset (if symptomatic) or their last possible Zika virus exposure (if asymptomatic) before trying to conceive with their partner (3). New data published since then support an update to that interim guidance. CDC now recommends that men with possible Zika virus exposure who are planning to conceive with their partner wait for at least 3 months after symptom onset (if symptomatic) or their last possible Zika virus exposure (if asymptomatic) before engaging in unprotected sex. CDC now also recommends that for couples who are not trying to conceive, men can consider using condoms or abstaining from sex for at least 3 months after symptom onset (if symptomatic) or their last possible Zika virus exposure (if asymptomatic) to minimize their risk for sexual transmission of Zika virus. Recommendations for

men with possible Zika virus exposure whose partner is pregnant remain unchanged; these couples should be advised to consistently and correctly use condoms during sex or abstain from sex for the duration of the pregnancy (Table).

$\mathrm{CDC}$ continues to recommend shared patient-provider decision making, in which couples and health care providers work together to make decisions about timeframes to wait before trying to conceive after possible Zika virus exposure. Some couples might choose to wait shorter or longer periods after possible Zika virus exposure, based on individual circumstances (e.g., age, fertility, or details of possible exposure), clinical judgment, and a balanced assessment of risks and expected outcomes. Other guidance for preconception counseling and prevention of sexual transmission of Zika virus after possible Zika virus exposure remains unchanged (3).

TABLE. CDC recommendations for preconception counseling and prevention of sexual transmission of Zika virus among persons with possible Zika virus exposure — United States, August 2018

\begin{tabular}{|c|c|}
\hline Exposure scenario & Recommendations (update status) \\
\hline $\begin{array}{l}\text { Only the male partner } \\
\text { travels to an area with } \\
\text { risk for Zika virus } \\
\text { transmission and } \\
\text { couple planning }\end{array}$ & $\begin{array}{l}\text { The couple should use condoms or abstain from } \\
\text { sex for at least } 3 \text { months after the male partner's } \\
\text { symptom onset (if symptomatic) or last possible } \\
\text { Zika virus exposure (if asymptomatic). } \\
\text { (Updated recommendation) }\end{array}$ \\
\hline
\end{tabular}

Only the female partner travels to an area with risk for Zika virus transmission and couple planning to conceive

Both partners travel to an area with risk for Zika virus transmission and couple planning to conceive

One or both partners have ongoing exposure (i.e., live in or frequently travel to an area with risk for Zika virus transmission) and couple planning to conceive
The couple should use condoms or abstain from sex for at least 2 months after the female partner's symptom onset (if symptomatic) or last possible Zika virus exposure (if asymptomatic). (No change in recommendation)*

The couple should use condoms or abstain from sex for at least 3 months from the male partner's symptom onset (if symptomatic) or last possible Zika virus exposure (if asymptomatic). (Updated recommendation)

The couple should talk with their health care provider about their plans for pregnancy, their risk for Zika virus infection, the possible health effects of Zika virus infection on a baby, and ways to protect themselves from Zika. If either partner develops symptoms of Zika virus infection or tests positive for Zika virus infection, the couple should follow the suggested timeframes listed above before trying to conceive. (No change in recommendation)*

Men with possible Zika virus exposure whose partner is pregnant

* Petersen EE, Meaney-Delman D, Neblett-Fanfair R, et al. Update: interim guidance for preconception counseling and prevention of sexual transmission of Zika virus for persons with possible Zika virus exposure-United States, September 2016. MMWR Morb Mortal Wkly Rep 2016;65:1077-81. 


\section{Summary}

What is already known about this topic?

Zika virus infection during pregnancy is a cause of serious birth defects. CDC previously released interim guidance on preconception counseling and prevention of sexual transmission of Zika virus in October 2016.

What is added by this report?

$\mathrm{CDC}$ now recommends that men with possible Zika virus exposure who are planning to conceive with their partner wait at least 3 months after symptom onset or their last possible Zika virus exposure before engaging in unprotected sex. This updated timeframe also applies to prevent sexual transmission of Zika virus.

What are the implications for public health practice?

These recommendations provide couples planning pregnancy with updated timeframes expected to reduce the risk for fetal Zika virus infection.

\section{Conflict of Interest}

No conflicts of interest were reported.

\begin{abstract}
${ }^{1}$ Division of Congenital and Developmental Disorders, National Center on Birth Defects and Developmental Disabilities, CDC; ${ }^{2}$ Division of Vector-Borne Diseases, National Center for Emerging and Zoonotic Infectious Diseases, CDC; ${ }^{3}$ Division of Reproductive Health, National Center for Chronic Disease Prevention and Health Promotion, CDC; ${ }^{4}$ Division of Global Migration and Quarantine, National Center for Emerging and Zoonotic Infectious Diseases, CDC; ${ }^{5}$ Division of HIV/AIDS Prevention, National Center for HIV/AIDS, Viral Hepatitis, STD, and TB Prevention, CDC.
\end{abstract}

Corresponding author: Kara D. Polen, kpolen@cdc.gov, 404-498-3914.

\section{References}

1. Rasmussen SA, Jamieson DJ, Honein MA, Petersen LR. Zika virus and birth defects - reviewing the evidence for causality. N Engl J Med 2016;374:1981-7. https://doi.org/10.1056/NEJMsr1604338

2. Moore CA, Staples JE, Dobyns WB, et al. Characterizing the pattern of anomalies in congenital Zika syndrome for pediatric clinicians. JAMA Pediatr 2017;171:288-95. https://doi.org/10.1001/ jamapediatrics.2016.3982

3. Petersen EE, Meaney-Delman D, Neblett-Fanfair R, et al. Update: interim guidance for preconception counseling and prevention of sexual transmission of Zika virus for persons with possible Zika virus exposure-United States, September 2016. MMWR Morb Mortal Wkly Rep 2016;65:1077-81. https://doi.org/10.15585/mmwr.mm6539e1

4. Moreira J, Peixoto TM, Siqueira AM, Lamas CC. Sexually acquired Zika virus: a systematic review. Clin Microbiol Infect 2017;23:296-305. https://doi.org/10.1016/j.cmi.2016.12.027

5. Deckard DT, Chung WM, Brooks JT, et al. Male-to-male sexual transmission of Zika virus - Texas, January 2016. MMWR Morb Mortal Wkly Rep 2016;65:372-4. https://doi.org/10.15585/mmwr.mm6514a3

6. Davidson A, Slavinski S, Komoto K, Rakeman J, Weiss D. Suspected female-to-male sexual transmission of Zika virus-New York City, 2016. MMWR Morb Mortal Wkly Rep 2016;65:716-7. https://doi. org/10.15585/mmwr.mm6528e2

7. Carroll T, Lo M, Lanteri M, et al. Zika virus preferentially replicates in the female reproductive tract after vaginal inoculation of rhesus macaques. PLoS Pathog 2017;13:e1006537. https://doi.org/10.1371/ journal.ppat. 1006537
8. Duggal NK, McDonald EM, Ritter JM, Brault AC. Sexual transmission of Zika virus enhances in utero transmission in a mouse model. Sci Rep 2018;8:4510. https://doi.org/10.1038/s41598-018-22840-6

9. Daiminger A, Bäder U, Enders G. Pre- and periconceptional primary cytomegalovirus infection: risk of vertical transmission and congenital disease. BJOG 2005;112:166-72. https://doi. org/10.1111/j.1471-0528.2004.00328.x

10. Enders G, Nickerl-Pacher U, Miller E, Cradock-Watson JE. Outcome of confirmed periconceptional maternal rubella. Lancet 1988;331:1445-7. https://doi.org/10.1016/S0140-6736(88)92249-0

11. Picone O, Vauloup-Fellous C, Cordier AG, et al. A series of 238 cytomegalovirus primary infections during pregnancy: description and outcome. Prenat Diagn 2013;33:751-8. https://doi.org/10.1002/ pd. 4118

12. Revello MG, Zavattoni M, Furione M, Lilleri D, Gorini G, Gerna G. Diagnosis and outcome of preconceptional and periconceptional primary human cytomegalovirus infections. J Infect Dis 2002;186:553-7. https:// doi.org/10.1086/341831

13. Nunoue T, Kusuhara K, Hara T. Human fetal infection with parvovirus B19: maternal infection time in gestation, viral persistence and fetal prognosis. Pediatr Infect Dis J 2002;21:1133-6. https://doi. org/10.1097/00006454-200212000-00009

14. Turmel JM, Abgueguen P, Hubert B, et al. Late sexual transmission of Zika virus related to persistence in the semen. Lancet 2016;387:2501. https://doi.org/10.1016/S0140-6736(16)30775-9

15. Arsuaga M, Bujalance SG, Díaz-Menéndez M, Vázquez A, Arribas JR. Probable sexual transmission of Zika virus from a vasectomised man. Lancet Infect Dis 2016;16:1107. https://doi.org/10.1016/ S1473-3099(16)30320-6

16. Atkinson B, Thorburn F, Petridou C, et al. Presence and persistence of Zika virus RNA in semen, United Kingdom, 2016. Emerg Infect Dis 2017;23:611-5. https://doi.org/10.3201/eid2304.161692

17. Barzon L, Percivalle E, Pacenti M, et al. Virus and antibody dynamics in travelers with acute Zika virus infection. Clin Infect Dis 2018;66:117380. https://doi.org/10.1093/cid/cix967

18. Barzon L, Pacenti M, Franchin E, et al. Infection dynamics in a traveller with persistent shedding of Zika virus RNA in semen for six months after returning from Haiti to Italy, January 2016. Euro Surveill 2016;21.

19. D'Ortenzio E, Matheron S, Yazdanpanah Y, et al. Evidence of sexual transmission of Zika virus. N Engl J Med 2016;374:2195-8. https:// doi.org/10.1056/NEJMc1604449

20. Frank C, Cadar D, Schlaphof A, et al. Sexual transmission of Zika virus in Germany, April 2016. Euro Surveill 2016;21:30252. https://doi. org/10.2807/1560-7917.ES.2016.21.23.30252

21. Gaskell KM, Houlihan C, Nastouli E, Checkley AM. Persistent Zika virus detection in semen in a traveler returning to the United Kingdom from Brazil, 2016. Emerg Infect Dis 2017;23:137-9. https://doi. org/10.3201/eid2301.161300

22. Harrower J, Kiedrzynski T, Baker S, et al. Sexual transmission of Zika virus and persistence in semen, New Zealand, 2016. Emerg Infect Dis 2016;22:1855-7. https://doi.org/10.3201/eid2210.160951

23. Huits R, De Smet B, Ariën KK, Van Esbroeck M, Bottieau E, Cnops L. Zika virus in semen: a prospective cohort study of symptomatic travellers returning to Belgium. Bull World Health Organ 2017;95:802-9. https:// doi.org/10.2471/BLT.17.181370

24. Jang HC, Park WB, Kim UJ, et al. First imported case of Zika virus infection into Korea. J Korean Med Sci 2016;31:1173-7. https://doi. org/10.3346/jkms.2016.31.7.1173

25. Joguet G, Mansuy JM, Matusali G, et al. Effect of acute Zika virus infection on sperm and virus clearance in body fluids: a prospective observational study. Lancet Infect Dis 2017;17:1200-8. https://doi. org/10.1016/S1473-3099(17)30444-9

26. Matheron S, d'Ortenzio E, Leparc-Goffart I, Hubert B, de Lamballerie X, Yazdanpanah Y. Long-lasting persistence of Zika virus in semen. Clin Infect Dis 2016;63:1264. 
27. Mansuy JM, Dutertre M, Mengelle C, et al. Zika virus: high infectious viral load in semen, a new sexually transmitted pathogen? Lancet Infect Dis 2016;16:405. https://doi.org/10.1016/S1473-3099(16)00138-9

28. Mead PS, Duggal NK, Hook SA, et al. Zika virus shedding in semen of symptomatic infected men. N Engl J Med 2018;378:1377-85. https:// doi.org/10.1056/NEJMoa1711038

29. Medina FA, Torres G, Acevedo J, et al. Duration of infectious Zika virus in semen and serum. J Infect Dis 2018. https://doi.org/10.1093/infdis/jiy462

30. Musso D, Roche C, Robin E, Nhan T, Teissier A, Cao-Lormeau VM. Potential sexual transmission of Zika virus. Emerg Infect Dis 2015;21:359_ 61. https://doi.org/10.3201/eid2102.141363

31. Nicastri E, Castilletti C, Liuzzi G, Iannetta M, Capobianchi MR, Ippolito G. Persistent detection of Zika virus RNA in semen for six months after symptom onset in a traveller returning from Haiti to Italy, February 2016. Euro Surveill 2016;21:30314. https://doi. org/10.2807/1560-7917.ES.2016.21.32.30314

32. Paz-Bailey G, Rosenberg ES, Doyle K, et al. Persistence of Zika virus in body fluids_preliminary report. N Engl J Med 2017;NEJMoa1613108. https://doi.org/10.1056/NEJMoa1613108

33. Reusken C, Pas S, GeurtsvanKessel C, et al. Longitudinal follow-up of Zika virus RNA in semen of a traveller returning from Barbados to the Netherlands with Zika virus disease, March 2016. Euro Surveill 2016;21:30251. https://doi.org/10.2807/1560-7917. ES.2016.21.23.30251

34. Atkinson B, Hearn P, Afrough B, et al. Detection of Zika virus in semen. Emerg Infect Dis 2016;22:940. https://doi.org/10.3201/ eid2205.160107
35. Mansuy JM, Pasquier C, Daudin M, et al. Zika virus in semen of a patient returning from a non-epidemic area. Lancet Infect Dis 2016;16:894-5. https://doi.org/10.1016/S1473-3099(16)30153-0

36. Russell K, Hills SL, Oster AM, et al. Male-to-female sexual transmission of Zika virus-United States, January-April 2016. Clin Infect Dis 2017;64:211-3. https://doi.org/10.1093/cid/ciw692

37. Sánchez-Montalvá A, Pou D, Sulleiro E, et al. Zika virus dynamics in body fluids and risk of sexual transmission in a non-endemic area. Trop Med Int Health 2018;23:92-100. https://doi.org/10.1111/tmi.13019

38. Wu D, Sun J, Zhong H, et al. A family cluster of imported ZIKV cases: Viremia period may be longer than previously reported. J Infect 2016;73:300-3. https://doi.org/10.1016/j.jinf.2016.06.008

39. de Laval F, Matheus S, Labrousse T, Enfissi A, Rousset D, Briolant S. Kinetics of Zika viral load in semen. N Engl J Med 2017;377:697-9. https://doi.org/10.1056/NEJMc1612600

40. Fréour T, Mirallié S, Hubert B, et al. Sexual transmission of Zika virus in an entirely asymptomatic couple returning from a Zika epidemic area, France, April 2016. Euro Surveill 2016;21:30254. https://doi. org/10.2807/1560-7917.ES.2016.21.23.30254

41. Musso D, Richard V, Teissier A, et al.; Recipient Epidemiology and Donor Evaluation Study (REDS-III) ZIKV Study Group. Detection of Zika virus RNA in semen of asymptomatic blood donors. Clin Microbiol Infect 2017;23:1001.e1-3. https://doi.org/10.1016/j.cmi.2017.07.006

42. Brooks RB, Carlos MP, Myers RA, et al. Likely sexual transmission of Zika virus from a man with no symptoms of infection-Maryland, 2016. MMWR Morb Mortal Wkly Rep 2016;65:915-6. https://doi. org/10.15585/mmwr.mm6534e2 